\title{
correspondence
}

\section{Proceedings against professor}

Sir,-In Nature recently under the heading 'Anti-nuclear critic faces dismissal' (October 23, 1975, page 636) it was maintained that Professor Jens Scheer is "head of a university department" and is threatened with dismissal apparently becausc he criticises the construction of nuclear power stations. Both statements are incorrect.

(1) The "head" of our department is elected democratically each year by the professors, students and technical personnel. Professor Scheer has never held this office, which is at present occupied by Horst Diehl.

(2) It is true that various disciplinary proceedings have been initiated against Professor Scheer but the reason for these measures is neither his criticism of the West German nuclear programme, which is shared by a number of his colleagues against none of whom have any such proceedings been taken, nor simply his membership of what we consider a rather insignificant Maoist group.

Your readers might infer from the article that the West German authorities disregard individual rights and use improper methods in order to silence their critics and that the true reasons for the initiation of disciplinary proceedings against Professor Scheer are not those which had been stated officially. Such an inference would be wholly unfounded; readers should be aware of the following facts.

On two separate occasions, Professor Scheer was involved, with others, in violent activities at the University of Bremen: in October 1973 a meeting of Christian Democrat students was broken up by force, and in September 1975 a press conference of the Students Committec was pelted with eggs and tomatoes. In both cases the university took out disciplinary proccedings against Professor Scheer. The earlier case, in which the Rector imposed a fine on Professor Scheer, is under appeal; the latter is still under consideration. Professor Scheer's action in 1973 also led to the District Court of Bremen sentencing him to three months imprisonment (suspended) and a fine of DM3,000. This too is under appeal.

Action has also been taken against Professor Scheer by the Senate of the Free Hanse Town of Bremen under the provisions of the Bremen Civil Servants Law. Since December 9, 1975, he has been under suspension on half pay as a result of his alleged anticonstitutional activities.

Yours faithfully,

Stefan von Aufschnalter

(Conrektor of the University)

Siegfrien BOSECK

HORST DIEHL

WOLIGang DREYBROIT

DiETER VON EHRENSTFIN

KLaus Haefner

PETER RYDER

HELMUT SCHWEgi.er

WOI.F SiEgerT

(Professors of Physics)

University of Bremen,

Bremen, West Germany

\section{Naming the blue-greens}

SIR,-Recently, in several publications, organisms hitherto known as bluegreen algae have been called "bluegreen bacteria". It is appropriate to consider the popular name of the Cyanophyceae in a scientific journal since words, especially those used in science, should have clearly defined meanings and should not be subject to passing whims or personal preferences.

Cohn, more than a century ago, associated the apparently non-nucleate blue-green algae with the bacteria in the division Schizophyta (Beitr. Biol. Pflanz, 1, 141-207; 1875). Chatton subsequently distinguished the characteristic cellular organisation of these types of organisms as "procaryotic", (Titres et travaux Scientifiques, Sète, Sottano, 1937), and on this basis Stanier and van Niel proposed a major taxonomic dichotomy among living organisms, establishing the Prokaryota and Eukaryota (J. Bact., 42, 437-466; 1941). Although the Prokaryota are essentially the same as the Schizophyta, rules of priority have evidently been waived and this distinction has become gencrally accepted. The eighth edition of Bergey's Manual of Determinative Bacteriology (Williams and Wilkins, 1974) refers to "the bluc-green algae" as "allied to bacteria and at a lcvel of equal importance ... to the remainder of the Kingdom" (that is the Prokaryotae). But this is not to say that they are to be considered as bacteria. If we were now to start referring to cyanophytes as 'blue-green bacteria', we would implicitly synonymise the words 'prokaryota' and 'bacteria'. To what useful end?

It is generally accepted that living organisms should be named according to one of three texts: the International Rules of Botanical, Zoological and Microbial Nomenclature. If a creature is to be 'moved' from onc kingdom to another, its whole taxonomic status has to be reviewed and may have to be revised. If those of a whole class were to be involved, this would entail a lot of extra, and in my opinion, unncessary work and headaches.

The word 'algae' has no clearly defined taxonomic meaning. It is a useful and convenient term for most nonvascular aquatic plants capable of photosynthesis with $\mathrm{O}$ : evolution. If the Cyanophyceac were to be shifted, lexicographically, from the algac to the 'bacteria', it would be necessary to change many other generalisations to conform with this transfer. For example, the primary producers which evolve $\mathrm{O}$.2 would include 'bacteria' as well as green plants. The photosynthetic 'bacteria' would include aerobes as well as anaerobes, would contain either chlorophyll $a$ or bacteriochlorophylls in thylakoids or associated with other subcellular clements, and would fix $\mathrm{CO}$. either with or without O.. evolution. Many of the seaweeds which often dominate tropical shores would have to be regarded as 'bacterial' growths. What would we gain by such verbal changes?

Unlike non-photosynthetic prokaryotes, blue-green algae rarely cause disease or decay, and thus relatively little money is spent on them. (Anyone who questions this should compare the budget of a bacteriology department with that devoted to the study of bluegreen algae.) But although cyanophycologists are in a less fortunate position than bacteriologists when it comes to funding for research, personal remuneration, or public support, they should not seek to better their lot by calling themselves blue-green bacteriologists. Scientists should not use words misleadingly for base ends. In spite of the fairly evident and generally accepted phylogenetic homogeneity of the Prokaryota, the distinction between the classes arc worth retaining. Although we may now handle them by similar technologics, yeasts are fundamentally fungi, cells from tissue cultures remain hasically animal or plant cclls, and bluc-green prokaryotes are, by accepted standards, algae.

\section{Yours faithfully,}

RALPH A. LEWIN

Scripps Institution of Oceanography, La Jolla, California 92037 